\title{
Harmonization of law
}

Citation for published version (APA):

Backhaus, J. G. (1997). Harmonization of law. METEOR, Maastricht University School of Business and Economics. METEOR Research Memorandum No. 039 https://doi.org/10.26481/umamet.1997039

Document status and date:

Published: 01/01/1997

DOI:

10.26481/umamet.1997039

Document Version:

Publisher's PDF, also known as Version of record

\section{Please check the document version of this publication:}

- A submitted manuscript is the version of the article upon submission and before peer-review. There can be important differences between the submitted version and the official published version of record.

People interested in the research are advised to contact the author for the final version of the publication, or visit the DOI to the publisher's website.

- The final author version and the galley proof are versions of the publication after peer review.

- The final published version features the final layout of the paper including the volume, issue and page numbers.

Link to publication

\footnotetext{
General rights rights.

- You may freely distribute the URL identifying the publication in the public portal. please follow below link for the End User Agreement:

www.umlib.nl/taverne-license

Take down policy

If you believe that this document breaches copyright please contact us at:

repository@maastrichtuniversity.nl

providing details and we will investigate your claim.
}

Copyright and moral rights for the publications made accessible in the public portal are retained by the authors and/or other copyright owners and it is a condition of accessing publications that users recognise and abide by the legal requirements associated with these

- Users may download and print one copy of any publication from the public portal for the purpose of private study or research.

- You may not further distribute the material or use it for any profit-making activity or commercial gain

If the publication is distributed under the terms of Article $25 \mathrm{fa}$ of the Dutch Copyright Act, indicated by the "Taverne" license above, 
Prepared for the New Palgrave Dictionary of Economics and the Law

\title{
Harmonization of Law
}

\author{
Prof. Dr. Jürgen G. Backhaus \\ Maastricht University, AE \\ P.O. Box 616 \\ 6200 MD Maastricht \\ The Netherlands \\ tel: $+31-43-3883652 / 3636$ \\ fax: +31-43-3258440 \\ email: f.schijlen@algec.unimaas.nl
}




\begin{abstract}
Harmonization of the law, in Europe and elsewhere, can be a theory driven process in which law and economics research (J.E.L. code K) can play an important role.

With the example of a recent German case, the Waterpenny case, and an established piece of legislation, the Civil Code, it is shown how economic reasoning can enter into the process of jurisdiction, but also legislation. Broader lessons can be drawn from these studies.
\end{abstract}

J.E.L. code: K 00

Key words: Decisions under uncertainty, efficient law harmonization of law 


\section{Harmonization of Law}

Harmonization of the law, in Europe and elsewhere, can be a theory driven process in which law and economics research can play an important role.

With the example of a recent German case, the Waterpenny case, and an established piece of legislation, the Civil Code, it is shown how economic reasoning can enter into the process of jurisdiction, as well as legislation. Broader lessons can be drawn from these studies.

\section{The German Waterpenny Case: A Paradigm for the Emerging Common Law of Europe: Context}

Sometimes, arcane cases come before the high courts and require a specific ruling. The German Waterpenny case (BundesVerfassungsGerichts Entscheidung, Gen. 413/88 and 1300/93) is such an instance. At stake was not just the issue of who ultimately would have to bear the costs of using artificial fertilizer that may contaminate groundwater. Rather, in settling this issue the court faced a decision space of uncertainty and had to settle a basic issue on which, in the future, an entire system of rulings settling liability claims would have to rely. The decision space was one of uncertainty and not risk (See Knight, [1921] 1971) because neither the set of conceivable outcomes nor the attributable probabilities can be known beforehand. Even the legal system in which the ruling would ultimately serve as a precedent could no longer be known since the German constitutional court, just as other highest courts within the European Union, now operates in the context of European harmonization efforts that link the different legal systems of European Member States - as well as of those aspiring to become members - one to another. There is substantial pressure toward a convergence of these legal 
systems, when by architecture and built-in procedures they operate according to different rhythms. Ultimately, common features and traits will become apparent, and these will be principles that may not have guided any single decision of courts or other rule makers but may be able to further understanding of the decisions and rules as if the latter had been guided by them.

Europe is an area with many different jurisdictions. The attempts at harmonization of law have focused on legislated law rather than on the free movement of legal professionals, still less on understanding how law is being made in the different constituent parts of the European Union. In this context, it has been suggested (See Kötz, 1992) that the American example be followed and economic analysis employed as a unifying framework. In particular, law and economics as a subdiscipline of economics may provide such a unifying ingredient. The more European lawyers, attorneys, barristers, prosecutors and judges as well as the rule-drafting civil servants think in terms of law and economics concepts, the easier it will be for them to settle their differences, as sharp as those may be in particular cases.

\section{Antecedents: The Origins of the German Civil Code}

The issue of legal harmonization is not new in Europe. Outstanding examples are the great codifications, such as the "Code Civile de Napoleon" and the German Civil Code. The German Civil Code can actually even be considered an explicit attempt at efficient legislation.

The German Civil Code can be seen as one particular illustration of efficient legislation. The Civil Code was, in its ultimate form, passed with the explicit input of the leading economists of 
their time in Germany, and based on explicit economic reasoning. How this came about is worth recounting briefly.

In 1848 when the first German democratic parliament convened in the Church of St. Paul in Frankfurt, there were no less than 56 different legal systems governing bills of exchange. This exceeded by far the number of Member States of the German Federation at that time. It is obvious that such splintering of the legal system stood in the way of the rapidly developing market economy, and it was therefore already an initiative of the Frankfurt parliament to pass a common German Civil and also Commercial Code. However, the parliament had a short life span, and it dissolved before it had even seriously started the task. There were new initiatives in 1866 and 1869 in the northern German Federation, the pre-cursor of the Reich, but only after the unification of the German states as a confederation of principalities in 1871 could the task be resumed, and this happened with initiatives in 1873 in both the imperial parliament and the imperial council (the representation of the confederated princes). In 1874 the precommission of five members was established, and in the same year in 1874 a commission of eleven was established under the chairmanship of Pape. This commission issued a report in 1887 , and the act of introduction with various drafts of by-laws was also issued in 1887 and 1889 in order to provide for a broad discussion. However, the editor of the leading economics journal in Germany at the time, the Jahrbücher für Gesetzgebung, Verwaltung und Volkwirtschaft im deutschen Reich (Annals of Legislation, Administration and Political Economy in Germany), Gustav (von) Schmoller with his colleagues in the German Economics Association (Verein für Socialpolitik), agreed that the draft was impractical because it did not build on established economic practices and their respective legal counterparts, rather providing a deductively reasoned set of norms based on the Roman law tradition, and hence not corres- 
ponding to the economic practices of a developed industrialized market economy. Entire issues of the journal were devoted to critiques of the draft act, with the articles by Otto (von) Gierke having the strongest influence. This unsolicited advice led to the establishment of a second commission in 1890 which provided a completely revised draft Code in 1895 which was duly passed, after stormy discussions in the imperial parliament, on July 1, 1896 with 222 votes in favour and 48 against, on July 14 in the imperial council, and ratified by the Emperor on

October 18. The Code took effect on January 1, 1900. And, with numerous smaller revisions, it has remained the same since. This episode illustrates again that efficient legislation is possible, altough it also illustrates that, had the economics profession not intervened, legislation would probably have been imposed that would have burdened the German economy with high and persisting transactions costs. The Code would not have become the export article it actually proved to become, still today.

\section{Reprise: The Waterpenny Case Continued}

Instead of harmonizing law by codification, the German waterpenny case, which not only vindicates the Coase theorem as a conceivable tenet of legislation, but also deals with a problem recurring in every one of the Member States of the European Union, provides a good example for showing how the theory driven process of harmonization of European law could take place without infringing on the sovereignty of any one Member State. Hence, European legal harmonization may not only result in but even require efficiency in statute law.

When the waterpenny decision was published, there was an outburst of popular discontent with 
the constitutional court. (See e.g. Frankfurter Allgemeine Zeitung, 1996) Rarely has the constitutional court been so harshly criticized in the popular press (with only one recent instance rivalling the waterpenny commotion, when the court ruled on the separation of church and state) The farmers were said to be dumping their "poison" on the fields, and now they were being bribed to impose less harm on the natural resource of water. Under the cloak of the market economy, this political instrument appeared, in violation of the "polluter pays principle”, "a late ["spät”] victory of Lothar Späth, but defeat of reason”. (Lothar Späth had been the Prime Minister of the state of Baden Württemberg where the water penny was initiated at the behest of economists from the University of Constance. The Prime Minister had later resigned over a travel funding dispute and started a new career as a promoter of industrial development in the new federal state of Thuringia) In the face of such steamy rhetoric, it is probably worth considering the case itself. It had been brought by water authorities in Baden Württemberg and Hesse against the states of Baden Württemberg and Hesse (separately), claiming violation of the Federal constitution. For extracting groundwater, water authorities in Baden Württemberg had been charged between one and ten pfennigs per cubic meter, in Hesse between ten and fifty pfennigs, eventually one Mark per cubic meter.

\section{The Waterpenny Case: Technical Issues}

The total revenue from these levies amounted to between 145 and 165 million German Marks per year in Baden Württemberg and between 25 million German Marks and eventually 160 million German Marks in Hesse. The authorities claimed violation of articles 2.1 Basic Law 
(general guarantee of freedom and personal integrity), 3.1 (equality), 12.1 (freedom of choice of profession and line of business), 14.1 (guarantee of private property) as well as procedural violations. Violation of article 12 had been claimed only by the paper industry, which had joined the suit.

A definitional issue blurs a clear cut analysis of the case. Under German law, there is a difference between fees charged for specific services rendered by a public institution, special charges levied for specific purposes, taxes and prices. Roughly speaking, fees (Gebühren) require specific services rendered and in general have to mirror in value the benefit provided or the costs of the provision. The revenues from charges (Abgaben) have to be committed to the specific purpose for which they are levied, i.e. they have to be earmarked. Taxes (Steuern) are levied for the general fund with no specific offsetting benefit granted, while prices (Preise) are subject to the forces of supply and demand. Under this terminology, the states could not levy a tax for lack of competence, the water charges could not qualify as fees or prices, nor could they qualify as special charges (Sonderabgaben) because the beneficiaries were not identical to the stated purpose. Most of the argument revolves around these definitional issues, through which the court cut by stating that the traditional notions and definitions were irrelevant and only the function of the policy instrument had to be considered in the light of their guarantees and protections provided by the fiscal constitution. (Statement (Leitsatzt) 1) Secondly, the court decided that water as a natural resource was a common property, using it created a specific advantage which could be taxed away (Abschöpfen) either in part or in whole.

On several occasions, the court explicitly cites "economists" and "economics" and even uses 
economic jargon, such as "externalities", "market failure" and functional instruments to "internalize" external costs. It cites incentive effects of the water penny and legislative discretion between different functional instruments. Finally, the court emphasizes the care that the legislatures have taken in preparing the legislation in Baden Württemberg and Hesse relying on experts in environmental economics and environmental law and the overwhelming consensus of these experts in drafting their respective legislation.

This is not the first time economics has taken a prominent position in German law. Harmonization of law can also be effected through legislation, and here again economics can play an important function, as the previously discussed legislation of the Civil Code suggests. [sect. II]

From an economic point of view, the implications of the Waterpenny legislations in Baden Württemberg and Hesse are clear enough. The ecological problem of reducing water polution through fertilizer use can clearly and effectively be addressed by subsidizing the farmers and taxing the water authorities, a standard economic solution. However, the poluter pays principle is being invoked from an equity point of view. Although the Waterpenny levied on the authorities and generating the subsidy to the farmers is not more burdensome to the consumers of water than the zero alternative which involves high costs of water cleaning, the poluter pays principle is charged with political overtones that defy standard public finance analysis and belong to those political premises that the economic analist has to take for granted. From the point of view of legal harmonization, the relevant theoretical aspects involve the position of the Coase theorem in jurisdiction, a specific economic theory of institutions developed by the court under the name of a theory of functions, and the doctrine of legislative due care.

\section{Externalities and Market Failure}


With this decision, the constitutional court in Karlsruhe has juxtaposed the economic principles of neo-classical public finance with the received doctrine that served to classify public revenues. By buying into modern public finance, which is a dogmatic system by itself, the court has substituted for an old dogmatic system - the old classificatory doctrine of public revenues that had strong public law underpinings - by the modern theory of public finance as it has emerged consequent to the development of the theory of market failure. (See Bator, 1958) From the point of view of constitutional legal doctrine, this juxtaposition did not require any particular change in methods. One economic system can serve just as well as the other, just as long as there is a linkage that can translate the economic notions into legal ones. That linkage is provided by the theory of functions which the court has been using for some two decades now in the most diverse sub-areas of constitutional litigation.

\section{The Theory of Functions}

For many years now, the court has developed the theory of functions (of legal institutions or legal arrangements) that serves as a port of entry for almost any kind of a scientific argument into its jurisdiction, much as the Brandeis brief does in the United States. (See Senn, 1998) The court has had ample opportunity to test this theory, since the German constitution has been broadly conceived and can be interpreted and tested as serving to protect many specific institutions. For instance, such institutions as capital markets, labour markets, collective bargaining and its equilibrating forces, private property, vested rights of university scholars in their traditional forms of research, corporate forms such as joint stock companies, limited liability companies, limited liability companies on shares etc., to name just a few, are all 
protected under the constitution in their basic viability. The doctrine of viability which serves as the standard test that the court uses in order to judge the constitutionality of particular acts of parliament requires that the basic function of the institution in question not be impaired. A rule passes muster before the constitution if the institution in question, such as a corporation under the co-determination act, to name just one example, is still viable after application and implementation of the act under review. In order to determine whether an institution is viable under changed conditions, one has to determine first what constitutes its viability, i.e. in the notions of the court, what is its function. If, for instance, the function of the corporation is held to be that capital owners have a chance to invest and earn a return on their capital that reflects both the scarcity of capital and their business acumen, and to give workers a chance to be employed in a particular community, then these three functions must be possible to be discharged even after any rule has been imposed and without major impediments in the sense that such impediments cannot be overcome by the kind of management that can be expected to run such a corporation. Likewise, and to move the discussion closer to the case at hand, a specific public revenue source may be said to have the function to fulfill the revenue needs of a specific public institution that is dedicated to a specific need (Anstalt), and then the doctrine has to serve the purpose of protecting both the institution in terms of its revenue needs and the captive customers of the institution from overcharging. This is the reason for the dogmatic theory of revenue sources that the court cut through for the case at hand. It argued, instead, that a Pigouvian tax (the court did not use that term) is not a revenue seeking instrument of taxation but rather an incentive oriented instrument to seek a particular response on the part of the tax payer, and hence it falls outside the received doctrine. Then the purpose must be to show that the function of affecting those incentives in the desired manner can well be accomplished by the instrument used and in the way the instrument is being used. Hence, if the 
desired purpose is to reduce reliance on the natural resource of water by reducing water consumption, and if it can be shown that a water charge imposed on the water authorities and passed along to the customers serves that purpose, then this specific fiscal instrument can be considered functional and it therefore passes the constitutional test.

Yet a popular sentiment insists that the water penny flies in the face of the "polluter pays principle" and therefore violates the most basic principle of civil law. Of this, the court had to find an answer in terms of its theory of functions, which it did. Nothing in the theory of Pigouvian taxes implies that the charges levied on those whose behaviour imposes externalities on others have to benefit those very inducers of externalities, nor need they be used for otherwise containing harm resulting from the externalities. Under Pigouvian doctrine the revenues from the charges, if they occur, can be used for any purpose. The point of the Pigouvian levy is to correct for an externality. Pigou cuts through the link made by Wicksell (1896) always to consider public outlays and public revenues together as one and only one decision. So the court argues correctly that it is within the discretion of the government to levy the charge, and it is likewise within the discretion of the government to use the resulting revenue according to its policies. Furthermore, the court argues that if a programme can be designed that uses the revenues so as to further the policies envisaged, nothing in the test of functionality prevents a government from pursuing that course.

It is here that the Coase theorem enters. The "polluter pays principle" does not make a distinction between allocation and distribution in an economy. The agent who "causes" an externality is responsible in the sense of being liable, that is he is responsible for correcting the allocation of resources as well as the resulting redistribution of income or wealth. The Coase theorem, 
instead, makes the standard distinction in economics that separates issues of the allocation of resources from issues of income or wealth. In order to achieve this result for the water penny, that is in order to reject the argument that the consumers who ultimately bear the burden of the water penny, private households, industrial corporations etc. should also somehow benefit from the charge intended to reduce water consumption, the court has to disconnect the allocation part: creating incentives for prudent water use; from the distribution aspect: who benefits from the revenues of the water penny? Since the Coase theorem is the vehicle for this argument, the court invokes the consensus among economists (the assumption by the court is correct. Ronald H. Coase had received the Nobel Prize in economics about when the litigation started) and through its theory of functions applies the Coase theorem to the water penny case.

By using the theory of functionality as a vehicle to introduce the evidence from social sciences into jurisprudence and notably the jurisdiction of the constitutional court, the court runs the risk of using theoretical results that have not been sufficiently corroborated. The results from social science research are, of course, always subject to the caveat that 1. conditions may change and

2. the evidence may simply have been misleading and what appeared to have been a thorough result, for instance, may rather be the result of spurious correlations.

While some courts in the United States have strongly relied on even recent social science research results in ordering strong measures, (the bussing decisions on the basis of James Coleman's research being one particularly conspicuous example), the German constitutional court has been more circumspect in designing a test with a specific consequence. It is here that the notion of legislative due care (Sorgfaltspflicht des Gesetzgebers) comes in. 


\section{Legislative Due Care}

Repeatedly, the German constitutional court has offered this reasoning in upholding controversial legislation. The instance was probably pioneered when the university constitution act was challenged, and it was perfected when the co-determination act of 1976 was under review. In such instances, when a specific arrangement due to a rule, an act or the composite result of different rules, acts, rulings etc. result in a specific clearly circumscribed outcome and parties claim to be violated in their basic rights, the functional test as described above for the institution in question is being applied. For instance, it could and has been argued that the water penny makes it impossible for the Hessian paper industry to compete fairly in international paper markets, against foreign competition to supply the big printing locations in Frankfurt. Against this has to be weighed the concern for water conservation which can, so the functional argument for the water penny goes, be accomplished by on the one hand discouraging water use by end consumers and on the other hand discouraging water pollution by farmers through fertilizers and (possibly) pesticides. Yet, what if farmers cannot be discouraged from polluting groundwater, and end consumers cannot be discouraged from using ever increasing amounts of water, with water authorities being rendered unable to make ends meet and fulfill their functions? In that case, the court has consistently argued, the factual evidence on which the decision rested, that has been introduced through the functionality theory, is erroneous; and consequently, the decision may be (but also may not be) erroneous as well since, ex falso quodlibet! In that case, and if the institution in question can clearly not perform the function attributed to it by the legislation and the court, it is the duty of the legislature to correct the act of parliament. (If parliament does not re-enact, the court will correct the law by substituting it through its ruling). The German parliament had repeatedly (but not often) to 
work under this regimen.

This requirement to correct an erroneous act of parliament, is to my knowledge, as far as constitutional courts go an invention of the judges in Karlsruhe. It is an interesting fruit of the eternal German Werturteilstreit, the struggle over the meaning of different scholarly methods, and it is the ultimate corrective on the doors swung wide open to introduce social science evidence into jurisdiction. The requirement to correct erroneous legislation opens the door as wide as possible to introduce empirical social science evidence. Yet, it provides its own regulator in imposing a duty of correction on the parliament. Which one wants to repeal his own legislation because of factual errors about its consequences? Given the requirement of erroneously based acts of parliament to be subject to review, and given the traditional emphasis on certainty in the law that characterizes every Western legal system, the court designed a doctrine of due legislative care in order to safeguard against sudden reversals of jurisdiction and legislation. In addition to considering the constitutionality of a particular arrangement such as an act of parliament, a directive, European legislation involving German persons (legal or personal), lower court rulings or administrative rulings, the constitutional court has designed a two pronged procedure to allow social science evidence into the law. On the one hand, through the theory of functions, almost any type of respectable social science result can enter right into the decisions of the court. This is even the case for feminist jurisprudence as long as it is scholarly. The current president of the court promotes this course. On the other hand, the court has always insisted, and consistently does so, that legislatures, when introducing social science evidence into their considerations as they should, should also take due care in not glossing over the evidence and being circumspecting in gathering enough of it. Hence, in 
particular when far reaching decisions have to be taken and much evidence mounted by either side before the parliament and its committees, the court raises the standard of legislative care in requiring extensive hearings prior to the legislation. That is if any parliament, either one of the sixteen constituent federal states or the federal parliament itself, wishes to pass an act of legislation that can be expected to be challenged in front of the constitutional court, that parliament now has to engage in an extensive procedure of fact finding and hearings prior to legislating, just in order to make sure that the act under controversy will survive before the constitutional court, of course always under the proviso that the evidence does not overwhelmingly change. Hence, by on the one hand lowering the threshold for admissible evidence and opening the doors for social science research results, the court at the same time has increased the threshold of evidence on the legislatures by forcing them to consider and divulge that same social science evidence beforehand. This may be the wider implication of the functionality theory for German jurisdictions. It amounts to a strong emphasis on background law and a severe discouragement of deal law.

By upholding the Waterpenny legislation of the states of Baden Württemberg and Hesse, the court, from the point of view of legal harmonization did three things: it first introduced the Coase theorem explicitly into jurisdiction and thereby opened the door for other aspects of ecoomic analysis to follow; secondly, it re-affirmed its theory of functions implying that legislation can be criticized from a transactions cost and property rights point of view if it can be shown that it renders economically relevant institutions, operationally inefficient; and thirdly, the theory of legislative due care re-affirms a type of liability for legislatures that do not adhere to this quality standard with legal consequence of remedial requirements.

\section{European Implications}


From a European point of view, the musings of the German constitutional court over the implications of the provisions of the German basic law of 1949 may appear to be rather immaterial. What is the law in Kehl may not necessarily be the law across the River Rhine in Strasbourg. Yet, the specific approach taken by the court in interpreting this Basic Law, the main provisions of which can, by the way, also be found in various European treaties, by far exceeds the boundaries of the German territories. First of all, legal doctrine is also a scholarly discipline that is internationally interconnected. The so-called German Rechtskreis also includes Greece and most of the Central European countries in transition. So, nolens wolens, German legal doctrine enters the doctrine of other European states as well. These states are members of the Council of Europe, and in that capacity they also influence the process of European legal harmonization. Others are members of the European Union and in that capacity they enter their concepts into the process of European harmonization in law.

A more important because less obvious element needs to be emphasized. The law in any country deals with the behaviour of people, and the social sciences have only in the last one hundred years taken a meteoric rise, while law as a scholarly discipline is several thousand years old. This scholarly confrontation has been met in different ways by different legal systems, but the American system with the Brandeis brief and the German system with the theory of functionality have been particularly open to social science research. Social science itself is international, and social scientists are competing internationally, subjecting their research to international scrutiny as it appears. Hence, social science research is becoming ever more powerful as an element of the set of data anybody, and therefore also a judge, needs to consider. That legal doctrine will gain a lead that finds a way to systematically integrate social 
science research into jurisdiction without compromising the core of the body of the law. With its pioneering decisions, of which the water penny case is only one, the German constitutional court has shown how this integration can be accomplished without doing damage to the core of the law. In doing this, the court, of course, does not export German jurisprudence in the sense of the specific relevant stipulations of German legislation, including the Basic Law, into other countries undergoing the same process of harmonization; what it exports is the specific method that is at variance with, for instance, the French method of jurisprudence that is based more strongly on Latin doctrine and emphasizes specific notions and their interpretation. The dispute over the classification of taxes is a very good point of illustration, as in that area Germany used largely to follow French administrative legal doctrine.

In opening this door to social science, and also providing for the requisite safeguards that any high court needs to maintain when admitting uncontrollable streams of evidence, the court necessarily opted for those social sciences that have the strongest evidence to marshal. At the present moment, economics is among these sciences, and law and economics is the discipline through which the results of economic science can be filtered into legal doctrine. Economic science, as any social science, is, of course, international and as such not bound by specific jurisdictions. In this sense, active law and economics research that filters into the decisions of high courts is itself a motor of the harmonization of law to the extent that courts are willing to follow the example of the German constitutional court, as it has been demonstrated in the water penny case.

\section{Bibliography}


Bator, Francis, (1958), The Anatomy of Market Failure, Quarterly Journal of Economics, 72, pp. 351-379

Frankfurter Allgemeine Zeitung, (1996), 17 February, Nr. 41, p. 2.

Knight, Frank (1921), Risk, Uncertainty and Profit. (Boston: Houghton Mifflin), Chicago: University of Chicago Press, 1971

Kötz, Hein (1992), “A Common Private Law for Europe”. In: Bruno de Witte and Caroline Forder (eds.), The Common Law of Europe. Deventer: Kluwer, pp. 31-42.

Senn, Peter, (1998), "Science as a Source of the Law", in Jürgen Backhaus (ed.) The Elgar Companion to Law and Economics, Aldershot: Elgar. (prior to publication available from ..... the author and the editor)

Wicksell, Knut, Finanztheoretische Untersuchungen, Jena: Gustav Fischer, 1896. 